\title{
Factors That Influence The Interest In Using Tax Consultant Services
}

\author{
Rina Hartanti and Muhammad Nuryatno \\ Fakultas Ekonomi dan Bisnis \\ Universitas Trisakti, Jakarta, Indonesia \\ Email: rinahartanti1@gmail.com,nanotrisakti2@gmail.com
}

\begin{abstract}
The aim of the study is to examine the effect of tax sanction assertiveness factors, knowledge of taxation, taxpayer motivation, and the tax authorities' service quality on the interest in using tax consultant services. Data was obtained by distributing 200 questionnaires to all personal taxpayers located in the working area in DKI as respondents and only 192 questionnaires were successfully filled out and returned, hence, analyzed using Structural Equation Models (SEM). The result of the study showed: (1) Tax sanction assertiveness does not affect the interest of taxpayers in using tax consultant services. (2) Knowledge of taxation has a positive and significant effect on the interest in using tax consultant services. (3) Motivation of taxpayers has a positive and significant effect on the interest in using tax consultant services. (4) Tax authorities' service quality does not affect the interest in using tax consultant services.
\end{abstract}

Keywords: Tax sanction assertiveness, knowledge of taxation; Motivation of taxpayers, Tax authorities' service quality, Interest in using tax consultant services.

\section{INTRODUCTION}

As a developing country, Indonesia needs many sources of state revenue to finance development in various sectors, one of which is income derived from tax revenues. As it is known, tax is a levy that is based on the law (which can be imposed) by not receiving reciprocal services that can be directly demonstrated using (counter-achievement). In this case the government implements a self-assessment system in the implementation of taxation in Indonesia. With this system, all taxpayers are given the authority to determine the amount of tax payable themselves.

Taxpayers often find difficulties in calculating and reporting the amount of tax payable, they find a lot of complexity of tax regulations applied in fulfilling tax obligations in Indonesia and also the existence of personal taxpayers who lack knowledge of taxation and computer technology skills or other applications based online. The complexity of the tax regulations was justified by Finance Minister Sri Mulyani's statement in a seminar entitled "Budget Deficit Problem and 2017 State Revenue Optimization Strategy" in the Jakarta Parliament building, which states that Indonesia is the most complicated tax country (Arubone, 2017). It has stated that many taxpayers in Indonesia, both individual taxpayers and corporate taxpayers use tax consultant services in 
fulfilling their tax obligations in which they can avoid mistakes in calculating and reporting the amount of payable tax.

Furthermore Izza, $\mathbf{J}$ as Chair of the Indonesian Internet Service Providers Association (APJII) stated that the composition of internet users in Indonesia is only $38 \%$ or 100 million people from the total population of Indonesia which amounts to 252 million people (Kure and Muslim, 2016). The majority of the Indonesian population can access the internet and it should be able to support taxpayer compliance in paying taxes, especially the fulfillment of online tax obligations (DJPonline). But in reality taxpayers are not optimal in utilizing online taxation applications provided by the Directorate General of Taxes in fulfilling their tax obligations (Nugrahanto, 2018). The result of the study from (Hani and Sari, 2014) showed that the fact that most restaurant taxpayers in Medan city do not understand taxation procedures and experience difficulties in inputting their tax data, nevertheless they choose to use a tax consultant to help settle their tax obligations.

According to M. Misbakhun as a Member of the House of Representatives Commission XI taxes are the largest source of state revenue, where as much as $85 \%$ of sources of state income come from taxes (Ryandi, 2018). However, in the recording of BPS (Central Bureau of Statistics) of the total working population in the first quarter of 2018 as many as 127.07 million people, not all of them have NPWP or tax ID number (Sicca, 2018). It is quite alarming when viewed on a national scale on March 31, 2018, only 10,589,648 individual taxpayers who report their tax return from the total of 18 million taxpayers that should report (Alika, 2018). Compliance with individual taxpayers in reporting their tax obligations is influenced by many factors that influence it, one of which is the motivation of the taxpayer itself.

Human motivation is the whole process of human movement, including situations that encourage, impulse that arises in the individual, behavior caused, and the purpose of the final act of movement. Motivation that exists in the personal taxpayer can be the driver of the taxpayer to fulfill or not fulfill his tax obligations. Motivation also ultimately affects the thoughts of personal taxpayers to use or not tax consultant services in fulfilling tax obligations. James Alm as the President of Southern Economic Association, USA in the seminar "What Motivates Tax Compliance?" at the UGM Faculty of Economics and Business, said that tax compliance is very dependent on the understanding and motivation of individuals and companies to decide whether to pay or not pay taxes (Ika, 2017).

The other author (Mutia, 2014) showed that there is a significant and positive relationship between tax sanctions and tax compliance. It means that the higher tax sanctions are strictly enforced, the higher tax compliance will be. The reluctance of taxpayers to receive tax sanctions, both administrative sanctions and criminal sanctions, make taxpayers use tax consultant services to assist them in fulfilling their tax obligations.

Another factor that influences the compliance of personal taxpayers in fulfilling their tax obligations is the quality of tax services (tax officers). Fiskus is a tax official appointed by the government to carry out administrative duties and oversee the implementation of taxation, as well as imposition and collection of taxes on the public. Services on taxpayers aim to maintain satisfaction of taxpayers so that taxpayer compliance in fulfilling their tax obligations can increase. In other words, taxpayer compliance can be improved by providing good and quality services to taxpayers; on the 
contrary the services of tax authorities that are less favorable for taxpayers make them turn to tax consultants to assist them in fulfilling tax obligations.

In order to increase public awareness to pay taxes properly, the community as taxpayers need to be guided to be able to carry out their tax obligations properly and obediently, where the task of guidance is at the Directorate General of Taxes (DGT). Basically, the Directorate General of Taxes (DGT) always tries to improve its performance in an effort to provide services and guidance to taxpayers in fulfilling their tax obligations. DGT's efforts often drain a lot of resources and time, causing the DGT to lose focus in securing tax revenues which are its main task. The limited resources of time and human resources possessed by DGT have made DGT rely on tax consultants as other parties who can assist DGT in optimizing the functions of socialization, assistance functions, evaluation functions, and tax anti-avoidance functions by taxpayers in implementing tax obligations in Indonesia.

Several studies conducted by previous researchers form the basis of this research, including research by (Munabari and Aji, 2014) showed that tax knowledge and perceptions of tax consultants have a positive and significant relationship with interest in using tax consultant services. Research conducted by (Hartanto and Tjondro, 2013) showed that taxpayers 'perceptions of tax knowledge, super ego motives, tax apparatus services, and roles as taxpayers' representatives partially have a significant influence on the demand for individual taxpayers for tax consultant services in the Mulyorejo KPP , Surabaya.

Then researcher (Que, 2013) stated that tax sanctions and taxpayer motivation have a positive effect on the use of tax consultant services. Research from (Pontoh et al., 2017) stated that the motivation level of taxpayers, tax sanctions, and the quality of tax consultants partially has a positive significant effect on the use of tax consultant services.

No previous research has examined the effect of tax sanctions firmness on interest in using tax consultant services. Previous researchers have examined the influence of taxation sanctions firm on taxpayer compliance in fulfilling their tax obligations (Kristina et al., 2015; Rahayu, 2017; Surliani and Kardinal, 2014; Trifina and Wijayanti, 2016).

Based on the previous explanation and the results of previous research, the study is limited to only a few variables which are factors that influence the interest in using tax consultant services, such as the tax sanctions assertiveness, knowledge of taxation, motivation of taxpayers, and tax authorities' service quality, in terms of taxpayer perceptions personally registered in the tax service office area throughout DKI Jakarta. This limitation is given so that this study is more focused so that it can prove the consistency of the influence of these variables and the differences that may arise in this study, therefore it is felt the need to conduct research on "The Influence of Tax Sanctions Assertiveness factors, Tax Knowledge, Taxpayer Motivation, and Tax Authorities' Service Quality Against the Interest in Using Tax Consultant Services."

Based on the description of the background of the research above, a research problem can be formulated, namely: "Is the taxation sanctions assertiveness, knowledge of taxation, motivation of taxpayers, and tax authorities' service quality affect the interest in using tax consultant services?". 
The aims of this study is to prove whether the taxation sanctions assertiveness, knowledge of taxation, motivation of taxpayers, and tax authorities' service quality have a positive effect on the interest in using tax consultant services.

\section{THEORITICAL REVIEW}

Tax Sanction Assertiveness. Assertiveness is related to attitude. Attitude is an evaluative statement both pleasant and unpleasant towards objects, individuals, or events (Robbins and Judge, 2012). According to (Putra, 2016) stated that one's assertiveness can be seen from several characteristics, such as:

1. Consistent: Stay firm on the decisions taken and accept all the consequences.

2. Determining priorities and focus, Priority means that you can determine which is more important to do and not easily influenced by other parties. While the focus is: things that must be considered so as not to take the wrong decision.

3. Prepare solid decisions: Not reckless in making decisions, so that you can get maximum result.

Assertiveness is the ability to calmly express desire, what someone wants or does not want, and how the person wants to be treated (Hadfield and Hasson, 2017).

Provisions regarding tax sanctions for taxpayers and tax authorities are regulated in Article 39 of Law Number 28 of 2007 concerning General Provisions and Procedures for Taxation (Waluyo, 2017). One example of taxation sanctions against tax offenders is a tax evasion case carried out by Dhana Widyatmika, a former civil servant in the Directorate General of Taxes who was charged with a 12-year prison sentence and a Rp.1 billion fine for corruption that has caused losses to the state amounting to Rp 3.4 billion from Herly Isdiharsono to reduce the tax obligations of PT. Mutiara Virgo, where PT. Mutiara Virgo only pays Rp. 30 billion from the value of the obligation that should be Rp. 128 billion. In this case the total money disbursed by PT. Mutiara Virgo through Jhony Basuki as the director of the tax employee reached Rp 20.8 billion. The Attorney General's Office also appointed Herly Isdiharsono and Jhony Basuki as suspects in this tax fraud case (Bayu, 2016).

Taxation Knowledge. Knowledge is a system of ideas that corresponds to the system of things and is connected by beliefs (Sobur, 2013). Knowledge is all that is known about a field of life.

Knowledge of taxation is all that is known about the general provisions and taxation procedures, both in the form of knowledge of tax regulations, procedures for calculating and reporting the amount of tax owed the functions and roles of tax collection (Waluyo, 2017).

According to M. Misbakhun as a Member of the House of Representatives Commission XI, the existence of tax regulations that often change and the complexity of these regulations can make taxpayers difficult, for which tax consultants are needed to help taxpayers fulfill their tax obligations, especially taxpayers who lack knowledge taxation (Ryandi, 2018). The research from (Saad, 2014) stated that knowledge of taxation 
and tax complexity is seen as a factor that contributes to the behavior of non-compliance of taxpayers in fulfilling their tax obligations. Even if every taxpayer has the knowledge and understanding of adequate tax regulations, then it can be ascertained that the taxpayer will knowingly obey his tax obligations properly and correctly so as to avoid tax violations that result in taxation sanctions (Fitria, 2017).

Taxpayers Motivation. Motivation is a process that explains the intensity, direction, and persistence of individual efforts to achieve a goal (Robbins and Judge, 2012).

Motivation is the whole process of movement, including situations that encourage, impulse that arises in the individual, behavior caused, and the purpose or end of movement or action (Sobur, 2013). Motivation means arousing motives, arousing the power of motion, or moving someone or yourself to do something in order to achieve a satisfaction or purpose. Furthermore, what is meant by motives is a reason or impulse that causes someone to do something, take action, or behave in a certain way. Indeed motivation is not a neutral force; motivation is influenced by other factors, such as past experience, intelligence, physical abilities, environmental situation, life ideals, and so on. The research from (Sobur, 2013) stated that motivation is influenced by several elements of behavior that form a circle of motivation (motivational cycle), as follows:

1. Needs.

According to (Rosengren, 1974) needs are: Biological and psychological infrastructure that forms the basis of all human social behavior, and that a large number of biological and psychological needs causes us to act and react. The need in this case is explained by the psychological theory of motivation with the selfactualization approach from (Maslow, 1954) better known as Maslow's Hierarchy of Needs, namely: physiological needs, safety needs, love needs and have-owned (belongingness and love needs), the need for appreciation (esteem needs), the need for self-actualization.

2. Behavior

Human behavior is a reaction that can be simple or complex which is used as a means or tool so that the goal can be achieved, where behavior itself is a series of activities. The behavioral philosophy assumes that behavior change specifically produces relationships with changes in thinking or attitude.

3. Purpose

The purpose is to motivate behavior. The goal also determines how active the individual will behave. If the goal is interesting, the individual will be more active in acting. Objectives can be concrete objects or abstract.

When it is implied to the taxation, taxation motivation is a reason or encouragement that causes taxpayers to comply with or do not comply with their tax obligations, also decide to use or not to use tax consultant services in order to avoid taxation errors. Compliance with taxpayers according to James Alm is very dependent on the understanding and motivation of individuals and companies to decide to pay or not pay taxes (Ika, 2017).

Motivation of each individual taxpayer between one taxpayer and the other taxpayers must vary depending on the factors that influence it, for example: there are 
taxpayers always trying to report their tax obligations on time because of their motivation not to be subject to tax sanctions in the form of fines tax, and there are also taxpayers who report their tax obligations on time because of their motivation not to want any more administrative work in connection with the management of application for extension of tax liability reporting, even to fulfill this motivation the taxpayer uses the services of a tax consultant.

The Tax Authorities' Service Quality. Quality is the nature and total characteristics of a product or service that relates to its ability to satisfy customer needs (Kotler and Armstrong, 2012).

Consumer assessment of service quality occurs during the service delivery process. Services are not intangible, so to assess and measure service quality needs to understand the dimensions of service quality as a benchmark indicator of the effectiveness and efficiency of services (services) provided (Suzanto, 2011).

The dimensions of service quality according to (Parasuraman et al., 1988) consisted of five (5) dimensions, namely: Reliability, Responsiveness, Assurance, Empathy, Tangible Products.

Tax services are public services provided by tax officials or tax authorities to the public who are registered as taxpayers. This service is given to help taxpayers fulfill their tax obligations and to implement tax laws and are not oriented to profit or benefit.

From the explanation above it can be concluded that the quality of tax authorities services are: the ability of tax authorities (tax officers) to provide benefits to taxpayers (intangible) to meet the needs and expectations of taxpayers in fulfilling their tax obligations in accordance with tax legislation.

The various perceptions of taxpayers on service quality provided by tax authorities is the basis of the desire of taxpayers to use tax consultant services in fulfilling tax obligations.

The Interest in Using of Tax Consultant Services. According to (Trisnawati and Rusydi, 2014) interests are: psychological factors that are formed and developed because of innate influences and environmental influences. The interest is an individual aspect that is closely related to needs, where someone's interest will arise if something he sees is related to his own interests. The most dominant environmental influences affect a person's interests, where the initial interest is centered on the individual, then centered on other people and objects in the person's environment. Characteristics of interest include: the existence of a positive attitude and something pleasant about an object, and contains an award that will lead to the desire to do something. Therefore in relation to taxes, interest in using tax consultant services can be interpreted as psychological factors that shape the behavior of taxpayers to use tax consultant services in fulfilling their obligations in the field of taxation, which in its development is influenced by the environment

The interest of taxpayers on the use of consultant services can come from within the taxpayer as well as from outside the influence of the surrounding environment. The tax consultant profession in Indonesia has been started since 1970. In further developments, Director General of Taxation Robert Pakpahan stated that the number of tax consultants in Indonesia is only 3,500 (Nordiansyah, 2018). This amount is relatively small to support 
the performance of the Directorate General of Taxation in serving taxpayers to fulfill their tax obligations. The research of (Munabari and Aji, 2014) revealed that the more positive perceptions of taxpayers, the greater the interest of taxpayers using tax consultant services.

Conceptual Framework. Based on the theory previously explained and the result of previous studies, the framework can be formulated in figure 1 .

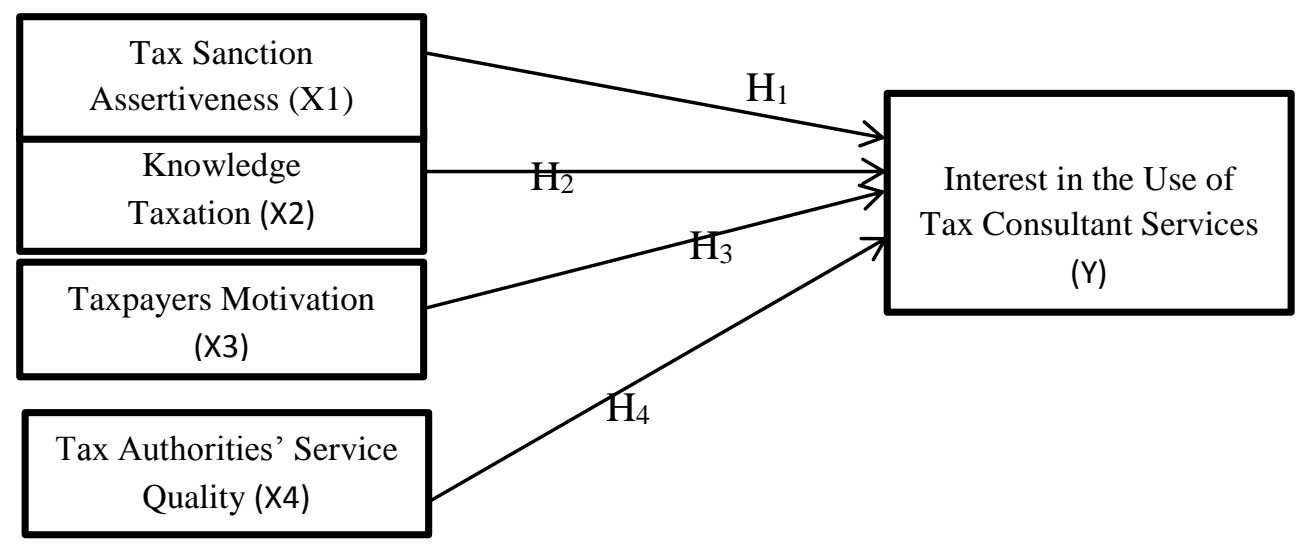

Figure 1. Framework of Conceptual 2018

Research Hypothesis. The results of previous studies indicate that the firmness of tax sanctions has a significant effect on taxpayer compliance in fulfilling tax obligations (Kristina et al., 2015; Rahayu, 2017; Surliani and Kardinal, 2014). Based on the results of previous studies, the research hypothesis can be made as follows:

H1: Tax sanctions assertiveness have a positive effect on interest in using tax consultant services.

Research from (Rahayu, 2017) showed a positive influence on tax knowledge on tax compliance. This means that the higher the tax knowledge will be the higher the desire of the taxpayer to submit a notification letter on time, so that it will increase taxpayer compliance. Research from (Hartanto and Tjondro, 2013) and Research from (Munabari and Aji, 2014) stated that knowledge of taxation has a positive and significant relationship to the interest in using consultant services. Therefore the hypotheses made in this study are as follows:

H2: Knowledge of taxation has a positive effect on interest in using tax consultant services.

Research from (Ginting et al., 2017) stated that the existence of motivation will affect the compliance and non-compliance of individual taxpayers in carrying out their tax obligations. The higher the motivation of individual taxpayers in terms of paying taxes, the higher the level of compliance, hence that tax revenues by the Directorate General of 
Taxes (DGT) are also increasing. Then the research result from Que (2013) and research from (Pontoh et al., 2017) showed that taxpayer motivation has a positive effect on the use of tax consultant services. Then the hypotheses made in this study are as follows:

H3: Motivation of taxpayers has a positive effect on interest in using tax consultant services.

Research from (Hartanto and Tjondro, 2013) stated that the service of the tax apparatus partially has a significant influence on the demand for individual taxpayers for tax consulting services in the tax office Mulyorejo area, Surabaya. Research from (Pontoh et al., 2017) stated that the quality of tax consultants partially has a significant positive effect on the use of tax consultant services. So the research hypothesis made is the following:

H4: The tax authorities' service quality has a positive effect on the interest in using consultant services.

\section{METHODOLOGY}

Population, Samples, and Data Collection Methods. Population refers to all groups of people, events, or things that researchers want to investigate for research (Sekaran and Bougie, 2018). The observation unit which is the population in this study is all individual taxpayers in Jakarta. The sample is a part (subset) of the population studied (Hermawan, 2017).

The sample in this study is an individual taxpayer within the DKI Jakarta environment. Taxpayers who are sampled in this study are taxpayers who are categorized as active taxpayers who have worked or own a business, who use the services of a tax consultant or do not use tax consultant services, and are domiciled or located in a working area of DKI.

The magnitude of the sample taken follows the SEM assumptions put forward by (Hair et al., 2010); and also follows the size of the sample according to (Roscoe, 1975) in (Now and Roger, 2018), such as: 1) Sample size is recommended 100 or at least 5 times the number of observations; 2) In most studies the right sample size is 31 to 500; 3 ) It is recommended that sample size is 10 times greater than the number of research variables for multivariate research, including multiple regression analysis. The authors have limited time to obtain data on the number of private taxpayers in DKI Jakarta, so this study took a sample of 200 samples as respondents of personal taxpayers in the DKI Jakarta area. Of the 200 questionnaires distributed, only 192 questionnaires were successfully filled out and returned. Then the questionnaire filled out by the respondents was inputted in the Excel software and SPSS 22.0 and then processed with the Amos 22.0 program.

Data collected is primary data and secondary data, where primary data is obtained by distributing questionnaires on research topics to respondents, while secondary data is obtained by conducting library studies on related research topics. 
The sampling technique is done by using a purposive sampling method, namely the sample is taken using certain criteria, and in this case the taxpayer selected as the object of this research is that meets the following criteria:

1. Personal tax payers who earn income from work or business.

2. Personal taxpayers domiciled or located in the DKI Jakarta work area.

3. Mandatory individuals who use the services of a tax consultant or who do not use the services of a tax consultant.

Data analysis method. Data analysis in this study was carried out using Structural Equation Models (SEM) techniques with the Amos 22.0 program.

Analyzing research models with SEM can identify the dimensions of a construct and at the same time measure the influence and degree of relationship between factors that have been identified dimensions (Ghozali, 2016). SEM analysis was conducted to test the relationship between the variables used in testing the theoretical hypothesis. SEM is one of the multivariate data analysis techniques which is a combination of path analysis and factor analysis (Hair et al., 2010).

Variable and Measurement Operational Definitions. The independent variables in this study are: Interest in the use of tax consultant services and dependent variables are: Tax sanctions assetiveness, Knowledge of taxation, Motivation of taxpayers, and Tax authorities service quality.

The interest in the use of tax consultant services can be interpreted as psychological factors that shape the behavior of taxpayers to use tax consultant services in fulfilling tax obligations, which in its development are influenced by the environment.

The firmness of taxation sanctions according to (Mardiasmo, 2018) is: firmness on the guarantee that taxation norms that contain provisions of tax laws and regulations are complied with by taxpayers.

Knowledge of taxation is all that is known about the general provisions and taxation procedures, both in the form of knowledge of tax regulations, procedures for calculating and reporting the amount of tax payable, the function and role of tax collection.

Taxation motivation is: a reason or impetus that causes taxpayers to obey or not comply with their tax obligations, also decides to use or not to use tax consultant services in order to avoid taxation errors.

Fiscal service quality is: the ability of tax authorities (tax officers) to provide benefits to taxpayers (intangible) to meet the needs and expectations of taxpayers in fulfilling their tax obligations in accordance with tax legislation.

The measurement of the taxation sanctions assertiveness uses three dimensions proposed by (Putra, 2016), namely: Consistent; Priority and focus; Solid decisions, and the three dimensions are measured by statement items, where each of these dimensions consists of five statement items for consistent dimensions and priority dimensions and focus, while solid decision dimensions consist of 4 item statements.

The measurement of tax knowledge variable uses three dimensions proposed by (Waluyo, 2017), such as: General provisions and taxation procedures; How to pay, fill, and submit annual tax notice electronically by DJPonline; Taxation regulations issued by 
the Ministry of Finance, where the three dimensions are each measured by five statement items.

The measurement of motivation variables of taxpayers uses three dimensions proposed by (Sobur, 2013), they are: Needs; Behavior; The purpose, where the three dimensions are each measured by four item statements.

The measurement of the tax authorities' service quality variables uses the five dimensions proposed by (Parasuraman et al., 1988): Reliability; Responsiveness; Guarantee; Empathy; Physical products, where each of the five dimensions is measured by four statement items for responsiveness dimensions; guarantee dimensions and dimensions of physical products. While the Empathy dimension is measured by five statement items.

In this study five variables were measured by using a Likert scale, from 1 to 5 , where: 1 = Strongly Disagree $(\mathrm{SD}), 2=$ Disagree $(\mathrm{D}), 3=\operatorname{Neutral}(\mathrm{N}), 4=$ Agree $(\mathrm{A}), 5=$ Strongly Agree (SA).

\section{RESULT AND DISCUSSION}

Descriptive Statistics. Respondents' perceptions of each variable are shown in Table 1.

Table 4.1 shows that the highest respondent's perception of each research variable is the taxpayer motivation variable with the overall average value generated by the respondent's answer of 3.51 with a standard deviation of 0.82 , while the lowest respondent's perceptions on the tax authorities service quality variable the overall average produced on the respondent's answer is 3.40 with a standard deviation of 0.84 . To measure descriptive statistics is using the SPSS 22 program.

\begin{tabular}{lccc}
\hline \multicolumn{4}{c}{ Table 1. } \\
\multicolumn{1}{c}{ Descriptive Statistics of Research Variables } \\
\multicolumn{1}{c}{ VARIABLES } & N & Mean & Standard Deviation \\
Tax Sanction Assertiveness & 192 & 3,49 & 0,93 \\
Taxation Knowledge & 192 & 3,47 & 0,94 \\
Taxpayer Motivations & 192 & 3,51 & 0,82 \\
Service Quality of the Fiscal & 192 & 3,40 & 0,84 \\
Interest in the Use of Tax Consultant & 192 & 3,41 & 0,86 \\
Services & & & \\
\hline
\end{tabular}

Source: Data processed (SPSS 22.0), 2018.

The standard deviation value of all variables: Tax sanctions assertiveness of 0.93; Tax knowledge of 0.94; Motivation of taxpayers is 0.82; Tax Authorities' service quality is 0.84 ; The interest in using tax consultant services is 0.86 . This means that the data distribution of all the variables studied tends to collect (centrally) and identify that the data collected is relatively good. 


\section{DISCUSSION}

The result of processing using the Structural Equation Model (SEM) using AMOS can be shown in figure 2.

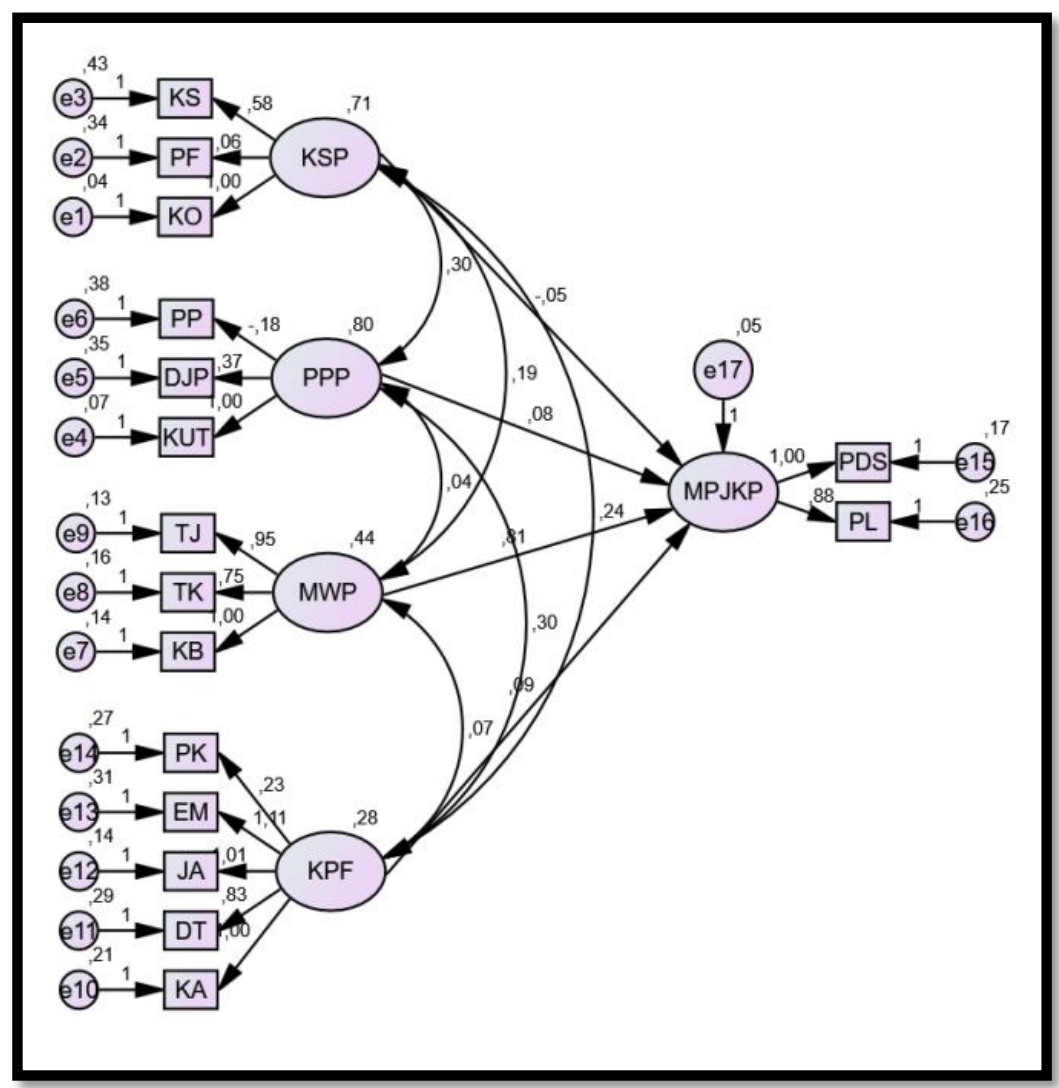

Figure 2. Result of Structural Equation Model (SEM) Source: Data Processed (Amos 22.0), 2018

The result of SEM processing in Figure 2. is summarized as the result of the hypothesis test in Table 2. below.

Table 2. The Result of Hypothesis Test

\begin{tabular}{|c|c|c|c|c|c|}
\hline & Hipotesis & $\underset{t}{\text { Coefficien }}$ & ProbTwoTai & $\begin{array}{l}\text { Prob } \\
\text { One- }\end{array}$ & Conclusi n \\
\hline $\mathrm{H}_{1}$ & $\begin{array}{l}\text { The tax sanctions } \\
\text { assertiveness has a } \\
\text { positive effect on the } \\
\text { interest in using tax } \\
\text { consultant services }\end{array}$ & $-0,052$ & 0,329 & 0.164 & $\begin{array}{c}\text { The hypothesis } \\
\text { is rejected }\end{array}$ \\
\hline
\end{tabular}




\begin{tabular}{|l|l|c|c|c|c|}
\hline $\mathrm{H}_{2}$ & $\begin{array}{l}\text { Knowledge of taxation } \\
\text { has a positive effect on } \\
\text { interest in using tax } \\
\text { consultant services }\end{array}$ & 0,081 & 0,156 & 0,078 & $\begin{array}{c}\text { Hypothesis } \\
\text { accepted }\end{array}$ \\
\hline $\mathrm{H}_{3}$ & $\begin{array}{l}\text { Motivation of } \\
\text { taxpayers has a } \\
\text { positive effect on } \\
\text { interest in using tax } \\
\text { consultant services }\end{array}$ & 0,807 & 0,000 & 0,000 & $\begin{array}{c}\text { Hypothesis } \\
\text { accepted }\end{array}$ \\
\hline $\mathrm{H}_{4}$ & $\begin{array}{l}\text { The tax authorities } \\
\text { service quality has a } \\
\text { positive effect on the } \\
\text { interest in using tax } \\
\text { consultant services }\end{array}$ & 0,088 & 0,413 & 0,2065 & $\begin{array}{c}\text { The hypothesis } \\
\text { is rejected }\end{array}$ \\
\hline
\end{tabular}

Source: Data Processed (Amos 22.0), 2018.

Based on the result of hypothesis test in Table 1, the following will describe the result of the research findings in more depth, where in interpreting the result of this study, the alpha used is $5 \%$ and $10 \%$.

Hypothesis 1. From the result of processing obtained an estimated coefficient of $-0,052$ which means that statistically there is no effect of the tax sanctions assertiveness on the interest in using tax consultant services.

These findings indicate that the hypothesis of tax sanctions assertiveness has a positive effect on the interest in using a tax consultant service is not proven (rejected). Thus Hypothesis $1(\mathrm{H} 1)$ is rejected.

The result of this study is in line with previous research conducted by (Trifina and Wijayanti, 2016) which stated that the firmness of tax sanctions does not have a significant effect on taxpayer compliance, because in fact many taxpayers are not subject to sanctions and also many taxpayers who do not know tax sanctions that will be received if the taxpayer commits a violation.

This is supported by the result research of (Cheisviyanny and Helmy, 2014) stated that compliance with tax obligations by taxpayers who are clients of tax consultants is higher than taxpayer compliance that is not a tax consultant client, where taxpayers seek tax consultants because they want to fulfill their tax obligations not because of the strictness of tax sanctions. This can be seen from the average value of respondents' answers of 3.50 on the item statement that states that all tax services offered by tax consultants are indeed very much needed.

Hypothesis 2. From the result of the processing obtained an estimated coefficient of 0.081 where the coefficient sign is in accordance with the hypothesis proposed in this study and showed that the proposed hypothesis is proven that knowledge of taxation has a positive effect on interest in using tax consultant services, thus Hypothesis 2 (H2) is accepted. With the result of the test in which showed a probability value of $0.156 / 2<0.10$ (alpha $10 \%$ ), it can be concluded statistically at the $95 \%$ confidence level that there is a positive 
influence of tax knowledge on the interest in using tax consultant services. This means that the higher taxation knowledge of taxpayers will further increase the interest of individual taxpayers using tax consultant services.

It is shown in the overall mean value generated from the respondent's answer to the knowledge variable of taxation is the mean value of 3.47 with a standard deviation of 0.94 which indicated that overall respondents tend to agree that the knowledge of taxation of personal taxpayers affects interest of the taxpayer concerned to use tax consultant services. From the respondent's answer it is also known that the highest average answer value is 3.86 in the item statement stating that "I have already had EFIN" or Electronic Filing Identification Number (DJP2). This means that personal taxpayers domiciled or located in the DKI Jakarta work area (respondents) already have tax knowledge about the obligation to have EFIN in fulfilling their tax obligations. The personal taxpayer understands the complexity of tax regulations so that the taxpayer feels the need to use a tax consultant to help fulfill his tax obligations.

The findings of this hypothesis was supported by the researches of (Munabari and Aji, 2014); (Hartanto and Tjondro, 2013) which that tax knowledge has a positive and significant relationship to the interest of taxpayers using consultant services.

Hypothesis 3. From the result of processing obtained an estimated coefficient of 0.807 where the coefficient sign is in accordance with the hypothesis proposed in this study. The result of the test showed that a probability value of $0,000 / 2<0.05$ (alpha 5\%), thus Hypothesis 3 (H3) is accepted, hence it is statistically proven to be a hypothesis of the positive influence of taxpayer motivation on the interest in using tax consultant services. This means that the higher the motivation of the taxpayer, the higher the interest of the taxpayer uses the services of a tax consultant.

It is shown that in the overall mean value generated from the respondent's answer to the taxpayer's motivation variable is 3.51 with a standard deviation of 0.82 is indicated that overall respondents tend to agree that the taxpayer's motivation influences the interest of personal taxpayers using services tax consultant. From the respondent's answer it is also known that the highest average score is 3.69 in the item statement which stated that "I think the tax consultant works professionally."

Of the 3 (three) dimensions that exist in the taxpayer motivation variable, the behavioral dimension is the dimension that has the highest mean value, which is equal to 3.60 with a standard deviation of 0.74 , this means the motivation of the personal taxpayer who influences his interest using tax consultant services due to the taxpayer's behavior that affects his mind that tax consultants work professionally, furthermore that they can help them fulfill their tax obligations. This is reinforced by a statement from (Sobur, 2013) the philosophy of behavior assumes that there is a change in behavior specifically resulting in a relationship with changes in thinking or attitude.

These findings support the research conducted by (Que, 2013) and research by (Pontoh et al., 2017), which stated that taxpayer motivation has a positive effect on the use of tax consultant services.

Hypothesis 4. From the result of processing obtained an estimated coefficient of 0.088 where the coefficient sign is in accordance with the hypothesis proposed in this study. But 
the result of the test showed a probability value of $0.413 / 2<0.10$ (alpha 10\%), meaning that statistically there is no influence on the quality of tax authorities' services on interest in using tax consultant services. Thus Hypothesis $4(\mathrm{H} 4)$ is rejected. This means that the hypothesis of a positive influence on the quality of tax service providers' on interest in using tax consulting services is not proven.

The findings of this hypothesis support the research conducted by (Munabari and Aji, 2014) concluded that the perception of Account Representatives (AR or fiskus) has a negative relationship and does not affect the interest of corporate taxpayers in using tax consultant services. This means that whether or not the quality of tax services (tax officers) does not affect the interest of individual taxpayers using tax consultant services. This might be due to personal taxpayers having more than 1 (one) source of income so that there is limited time to make the taxpayer interested in using tax consultant services.

Of the two dimensions that exist in the variable interest in the use of tax consultant services, the dimension of influence from within is a dimension that has the highest mean value of 3.49 with a standard deviation of 0.84 , this means compulsory interest personal tax using tax consultant services is more influenced by the influence of the taxpayer himself or herself, than the influence of the environment. It is shown that in the highest mean value generated from the respondent's answer to the dimension of influence from within himself or herself which is the mean value of 3.67 with a standard deviation of 0.78 on the item statement which stated that "I feel the use of services Tax consultant is an important requirement to be able to fulfill tax compliance."

The result of this study does not support the research conducted by Hartanto and Tjondro2(013) concluded that the service of the tax apparatus partially had a significant influence on the demand for individual taxpayers in using tax consulting services in the tax office Mulyorejo area, Surabaya.

\section{CONCLUSION}

Conclusion. Based on the discussion and analysis carried out, it can be concluded the results of the study are as follows:

1. The tax sanctions assertiveness does not affect the interest of personal taxpayers using tax consultant services, because all tax services offered by tax consultants are indeed needed by the taxpayer. Thus Hypothesis 1 (H1) is rejected. The result of this study is in line with the results of the study by (Cheisviyanny and Helmy, 2014); (Trifina and Wijayanti, 2016) which stated the firmness of tax sanctions do not have a significant effect on taxpayer compliance, because in fact there are many taxpayers who are not subject to sanctions and also many taxpayers who have not known the tax sanctions they will receive if the taxpayer commits a violation and taxpayers seek tax consultants because they want to fulfill their tax obligations not because of the strictness of tax sanctions.

2. Knowledge of taxation has a positive effect on the interest in using tax consultant services, moreover, Hypothesis $2(\mathrm{H} 2)$ is accepted. Personal taxpayers who are domiciled or located in the DKI Jakarta work area (respondents) already have tax knowledge about the obligation to have E-FIN in fulfilling their tax obligations and understand the complexity of tax regulations that make taxpayers feel the need to use 
tax consultants to help fulfill their tax obligations. The result of this study supported by the research by (Munabari and Aji, 2014); (Hartanto and Tjondro, 2013) stated that tax knowledge has a positive and significant relationship to the interest of taxpayers using consultant services.

3. Motivation of taxpayers has a positive effect on interest in using tax consultant services. Hypothesis $3(\mathrm{H} 3)$ is accepted. Motivation of personal taxpayers that influence their interest in using tax consultant services is due to the taxpayer's behavior that affects his mind that tax consultants work professionally, thus they can help them fulfill their tax obligations. The result of this study supported by the research of (Que, 2013) and research by (Pontoh et al., 2017), stated that the motivation of taxpayers has a positive effect on the use of tax consultant services.

4. The tax authorities' service quality does not affect the interest of private taxpayers using tax consultant services. Hypothesis $4(\mathrm{H} 4)$ is rejected. The interest of private taxpayers using tax consultant services is due to the influence in taxpayers who influence his mind that personal taxpayers feel using tax consultant services is an important requirement to be able to fulfill tax compliance, not because of good or not the quality of tax services. The result of this study supported by the research conducted of (Munabari and Aji, 2014) concluded that the perception of Account Representatives (AR or fiskus) has a negative relationship and does not affect the interest of corporate taxpayers in using tax consultant services. The result of this study do not support the research conducted by (Hartanto and Tjondro, 2013), stated that the service of the tax apparatus partially has a significant influence on the demand for individual taxpayers in using tax consulting services in the tax office of Mulyorejo area, Surabaya.

Implications. The managerial implications of the result of this study can be used as input for the tax consultant professional organization management to find out what factors influence the interest of individual taxpayers using tax consultant services, hence the tax consultant profession can better understand what strategies to do in improving quality its service as a taxpayer consultant, thus it can increase the interest of private taxpayers using their services.

While the theoretical implications of the results of this study is generally able to contribute to the theoretical literature about the factors that influence the interest in using tax consultant services in fulfilling tax obligations for taxpayers in Indonesia, including dimensions and indicators, as well as other variables that have not been studied.

Limitations. The limitations of this study are as follows:

1. This research is carried out only based on the perception of individual taxpayers as samples, which are located in the DKI working area.

2. This study is only limited to the variables of tax sanctions, tax regulations, taxpayers' motivation and quality of service of tax authorities.

Suggestion. Based on the limitations of existing research, some suggestions proposed for further research are as follows:

1. Further research can conduct research based on the perception of tax consultants as a sample of research and research extended to tax consultants located in work areas in 
other working provinces in Indonesia such as the provinces of Bali, West Java, North Sulawesi, and other large proportions, so the results of the research can more generalized.

2. Subsequent research can expand its research with other independent variables that influence the interest in using tax consultant services such as: The amount of tax consultant fees, Tax consultant independence and other variables.

\section{REFERENCE}

Alika, Rizky. (2018) Jelang Batas Waktu 31 Maret, 10 Juta Wajib Pajak Belum Lapor SPT (https://katadata.com/28-7-2018).

Arubone, Fauzi Bunaiya. (2017) MENKEU Sri: Indonesia Negara dengan Aturan Pajak Paling Rumit (https://ekbis.rmol.co/2-8-2018).

Bayu, Muhammad. (2016) Penggelapan Pajak (https://muhammadbayu05.blogspot.com/20-8-2018).

Cheisviyanny, Charoline dan Herlina Helmy. (2014) "Apakah Terdapat Perbedaan Tingkat Kepatuhan Antara Klien Konsultan Pajak dengan Bukan Klien?”. Jurnal WRA Vol. 2. (1), hal 333-348.

Fitria, Dona. (2017) "Apakah Terdapat Perbedaan Tingkat Kepatuhan Antara Klien Konsultan Pajak dengan Bukan Klien?”. Journal of Applied Business and Economics Vol. 4. (1), hal 30- 44.

Ghozali, Imam. (2016) Structural Equation Modeling, Metode Alternatif dengan Partial Least Square. Semarang: Badan Penerbit Universitas Diponogoro.

Ginting, Angela Vita Loka., Harijanto, Sabijono., dan Winston, Pontoh. (2017) "Peran Motivasi Dan Pengetahuan Perpajakan Terhadap Kepatuhan Wajib Pajak (Studi Empiris Pada WPOP Kecamatan Malalayang Kota Manado)". Jurnal EMBA. Vol. 5. (2), Juni.

Hartanto, Bobby dan Elisa Tjondro. (2013) "Pengaruh Persepsi Wajib Pajak Atas Pengetahuan, Super Ego Motives, Pelayanan Aparat Pajak Dan Peran Sebagai Wakil Wajib Pajak Terhadap Permintaan Wajib Pajak Orang pribadi Atas Jasa Konsultan Pajak di Wilayah KPP Mulyorejo Surabaya". Tax and Accounting Review, Surabaya: Universitas Kristen Petra. Vol. 3.(2) hal 1-14.

Hani, Syafrida dan Sari, Maya. (2014) "Analisis Masalah Sistem Pengawasan Pemungutan Pajak Restoran Dalam Peningkatan PAD Kota Medan”. Jurnal Pembangunan Perkotaan. Vol. 2. (1), Juni.

Hadfield, Sue dan Gill Hasson. (2017) Tegas Dalam Segala Situasi. Jakarta: Penerbit Buana Ilmu Populer.

Hair, J.F., Black, W.C., Babin, B.J., dan Anderson, R.E. (2010). Multivariate Data Analysis. Prentice Hall, Englewood Cliffs.

Hermawan, Asep. (2017) Penelitian Bisnis, Paradigma Kuantitatif: Pedoman Praktis untuk Mahasiswa S-1, S-2, dan S-3, Konsentrasi Pemasaran, Sumber Daya Manusia, Keuangan, dan Manajemen Operational, Jakarta: PT. Gramedia.

Ika. (2016) Kepatuhan Penyampaian Pajak Indonesia Rendah (https://ugm.ac.id/2-8$\underline{2018})$.

Kotler, P and Amstrong, G. (2012) Principles of Marketing. New Jersey: Prentice Hall. 
Kristina, Zirman dan Eka Hariyani. (2015) "Pengaruh Kesadaran Wajib Pajak, Kualitas Pelayanan, Ketegasan Sanksi Dan Kewajiban Moral Terhadap Kepatuhan Wajib Pajak Dalam Membayar Pajak Reklame". Jurnal Jom FEKON. Vol.2.(2), Oktober.

Kure, Emmanual dan Muslim, Abdul. (2016) Industri TIK Tumbuh Melebihi Ekonomi (https://www.beritasatu.com/2-8-2018).

Munabari, Wiza Fadheil dan Andri Waskita Aji. (2014) "Analisa Pengaruh Pengetahuan Perpajakan, Persepsi Tentang Konsultan Pajak, Dan Persepsi Tentang Account Representative Terhadap Minat Dalam Menggunakan Jasa Konsultan Pajak Pada Wajib Pajak Badan Di KPP Pratama Bantul". Jurnal Akuntansi Fakultas Ekonomi Universitas Sarjanawiyata Tamansiswa, Vol.2.(2) hal 64-79.

Mutia, Tita Putri Sri. (2014). Pengaruh Sanksi Perpajakan, Kesadaran Perpajakan, Pelayanan Fiskus Dan Tingkat Pemahaman Terhadap Kepatuhan Wajib Pajak Orang Pribadi (Studi Empiris pada Wajib Pajak Orang pribadi Yang Terdaftar di KPP Pratama Padang). Artikel Ilmiah Fakultas Ekonomi Universitas Negeri Padang, pp. 4-29.

Mardiasmo. (2018). Perpajakan. Yogyakarta: Andi Offset.

Maslow, A.H. (1954). Motivation and Personality. New York: Harper and Row.

Nordiansyah, Eko. (2018) Jumlah Konsultan Pajak Diharapkan Bertambah Dari 3.500 Orang (https://www.medcom.id/31-7-2018).

Nugrahanto, Bagas Rifky. (2018) Pembaharuan Data Wajib Pajak Tanpa Ribet (https://Pajak.go.id/10-8-2018).

Parasuraman, A., Zeithaml, V.A., and Berry, L.L. (1988) "SERQUAL: A Multiple-Item Scale For Measuring Consumer Perceptions Of Service Quality". Journal of Retailing. Vol. 64.

Pontoh, Fransiska Imelda, Inggriani Elim, Novi S Budiarso. (2017) "Analisis FaktorFaktor Yang Mempengaruhi Wajib Pajak Menggunakan Jasa Konsultan Pajak". Jurnal EMBA. Vol. 5.(2) hal 1226-1237.

Putra, Rizky Aldiransyah. (2016) Bagaimana Caranya Menjadi Seorang Pemimpin Yang Tegas (https://www.dictio.id/31-7-2018).

Que, Suwandy Stephany. (2013) "Faktor-faktor Yang Mempengaruhi Penggunaan Jasa Konsultan Pajak Oleh Wajib Pajak Orang Pribadi Di Kota Surabaya”. Jurnal Tax And Accounting Review Fakultas Ekonomi Universitas Kristen Petra, Vol.3.(2)

Robbins, P. S., dan Judge, A.T. (2012). Organization Behavior. New Jersey: Pearson Educations Inc.

Rosengren, K. E. (1974). Uses and Grafitications: A Paradigm Outlined, In J.G. Blumber and E.Katz (eds), The Uses of Mass Communication: Perspectives On Gratifications research. Sage. Beverly Hills, CA..

Ryandi, Dimas. (2018) RUU Konsultan Pajak, Kunci Reformasi Perpajakan. (https://www.jawapos.com/21-7-2018).

Rahayu, Nurulita. (2017) "Pengaruh Pengetahuan Perpajakan, Ketegasan Sanksi Pajak, Dan Tax Amnesty Terhadap Kepatuhan Wajib Pajak". Jurnal Akuntansi Dewantara. Vol.1(1) April.

Sekaran, Uma dan Roger Bougie (2018). Research Methods For Business (Metodologi Penelitian untuk Bisnis). Jakarta: Salemba Empat.

Sobur, Alex. (2013) Psikologi Umum Dalam Lintasan Sejarah. Bandung: Pustaka Setia. 
Sicca, Pradita Shintaloka. (2018) BPS: Jumlah Penduduk Bekerja Triwulan I 2018 Sebanyak 127,07 Juta (https://tirto.id/28-7-2018).

Surliani dan Kardinal. (2014) "Pengaruh Pemahaman, Kualitas Pelayanan, Ketegasan Sanksi Pajak, Dan Pemeriksaan Perpajakan Terhadap Kepatuhan Wajib Pajak Pada KPP Ilir Barat". Jurnal Akuntansi STIE MDP. hal 1-7.

Suzanto, Boy. (2011) "Pengaruh Kualitas Jasa Pelayanan Terhadap Kepuasan Pasien Pada Rumah Sakit Umum Kota Banjar”. Jurnal Ekonomi, Bisnis \& Entrepreneurship. Vol. 5. (1) April, 28- 44.

Saad, Natra. (2014) "Tax Knowledge, Tax Complexity and Tax Compliance: Taxpayers' View". Procedia-Social and Behavioral Science 109, $2^{\text {nd }}$ World Conference on Business, Economic and Managemnet - WCBEM 2013: 1069- 1075.

Trisnawati, K Mei dan M. Khoiru Rusydi. (2014) "Pengaruh Persepsi Dan Motivasi Terhadap Minat Mahasiswa Jurusan Akuntansi”. Jurnal Akuntansi Fakultas Ekonomi Dan Bisnis Universitas Brawijaya. hal 1-15.

Trifina, Wulan Butet dan Elvira Wijayanti. (2016) "Pengaruh Pengetahuan Perpajakan, Ketegasan Sanksi Perpajakan, Kualitas Pelayanan Petugas Pajak, dan Keadilan Perpajakan, Terhadap Kepatuhan Wajib Pajak". Prosiding SNA MK, 28 September 2016, hal 129-138.

Waluyo. (2017) Perpajakan Indonesia. Jakarta: Salemba Empat. 